\title{
Brazilian Foreign Policy for Immigrants and Refugees: New Concepts and Ethical Issues
}

\author{
Política Externa Migratória Brasileira: Novos Conceitos \\ e Questões Éticas
}

Roberto Rodolfo Georg Uebel*

\begin{abstract}
In the last decades, Brazil has received about 2,1 million immigrants, according to the Federal Police. In this contingency, migration flows from Latin America, Caribbean and West African coast can be highlighted, represented respectively by Haitians, Cubans, Venezuelans, Bolivians, Senegalese and Ghanaians.Thus, this paper will discuss the role of Brazilian Foreign Policy, as a legal tool to coordinate Brazil's immigration agenda and it aims to present the possibilities of the practical application of public policies for immigrants and refugees in the country based on the ethical challenges encountered by the Brazilian State and by the immigrants themselves, vis-à-vis to the foregoing context. Also, the paper will also present a brief immigration overview of Brazil, as well as launching for debate the concept of Brazilian Foreign Policy for Migrants and Refugees and its ethical challenges and delimitations in the Brazilian migration governance.
\end{abstract}

Keywords: Ethics; International Migration; Brazil.

* Doutor em Estudos Estratégicos Internacionais pela Universidade Federal do Rio Grande do Sul, professor do Curso de Graduação em Relações Internacionais da Escola Superior de Propaganda e Marketing (ESPM-POA). E-mail: roberto.uebel@espm.br. 


\section{RESUMO}

Nas últimas décadas, o Brasil recebeu cerca de 2,1 milhões de imigrantes, de acordo com a Polícia Federal. Neste cômputo, os fluxos migratórios da América Latina, Caribe e costa oeste da África se destacaram, representados respectivamente pelos haitianos, cubanos, venezuelanos, bolivianos, senegaleses e ganeses. Deste modo, este artigo discutirá o papel da Política Externa Brasileira, como uma ferramenta legal de coordenação da agenda imigratória do Brasil e tem como objetivo apresentar as possibilidades de aplicação prática de políticas públicas para imigrantes e refugiados no país baseada nos desafios éticos encontrados pelo Estado brasileiro e pelos próprios imigrantes dado o cenário corrente. O artigo apresentará também um breve panorama imigratório do Brasil, bem como lançará para debate o conceito de Política Externa Migratória Brasileira e seus desafios éticos e delimitações na governança migratória brasileira.

Palavras-chave: Ética; Migrações Internacionais; Brasil.

\section{Introduction}

Human mobility has always been a subject of studies and debates in the most varied aspects of modern science. While anthropologists devote themselves to investigate transcontinental migration causes, demographers analyse their population aspects, sociologists face the issues between being a migrant and the host society, psychologists observe the impacts on the mental health from the act of migrate and political scientists, geographers and internationalists estimate the political, territorial and international repercussions of migration.

However, over the last three decades with the advent of the technical-scientific informational globalization (SANTOS, 2017), which allowed the free circulation of capital, goods and information itself, but placed obstacles to human mobility-free, the ethical aspect of international migration has appeared most frequently in the collective, media, political and academic debate.

The migrant crisis in the Middle East and in the Mediterranean, of the Rohingya people and, more recently of the Venezuelans, have drawn social attention to the ethical treatment of migrants through the state, governments, international organizations and, ultimately, the most important one, through the civil society itself.

In this context, Brazil, the country that has received the most part of immigrants in South America in the last two decades (UEBEL, 2017), has 
not remained immune to discussions about the ethical parameters brought about by the migration of Latin Americans and Caribbean People and West Africans, the main groups of new immigrants, represented by Bolivians, Venezuelans, Haitians, Cubans and Senegalese.It is also worth noting the intense migration flow of Syrians to Brazil in the last three decades, due to the Civil War that takes place in Syria. Despite this article addressing economic migration, we cannot forget the contingent of asylum seekers and Syrian refugees in Brazil in recent years, which also imply ethical issues.

With changes in governmental and political agendas, transfigured into a polarization from a Centre-left progressive camp to a Far-right nationalist policy, the country included in its political agenda the migration issue, including its ethical dimension.

With that being said, this paper, which is divided into two sections, in addition to this Introduction and Conclusion, will address, through a bibliographic, documental, exploratory and qualitative research methodology, the ethical challenges arising from the International Relations field for discussion of international migration in the plan of the Brazilian Foreign Policy for Immigrants and Refugees, object of the doctoral thesis of the author. Thus, the first section will discuss the theoretical issues, presenting a brief immigration panorama in Brazil, a summary of the Brazilian Foreign Policy for Migrants and Refugees - concept proposed by the author -, the ethical challenges and the contemporary International Relations, and finally, the government institutional agenda, which will also be discussed in the second section, as a practical application of the present research object.

\section{Theoretical Questions}

In order to shed light on the theoretical debate about the international migrations to Brazil in the last two decades, vis-à-vis the ethical dimensions, it will be presented in the following four subsections a synthesis about 1) Brazil's immigration overview; 2)The Brazilian Foreign Policy for Migrants and Refugees;3) Ethical Challenges and Contemporary International Relations; and 4) The governmental institutional agenda as a path to practical application. These questions will be confronted in the next section with the objective to provide ethical application of the research problem in discussion. 


\subsection{Brazil’s Migration Overview}

Brazil's social, economic and cultural formation is the result of a multiethnic migration and it permeates the whole history of the country, from the colonial period of Portuguese exploitation to the present day, when the thirty years of national re-democratization are celebrated.

In the early days of Portuguese colonial exploitation, the immigration to Brazil took place in an ordered way, first by the Portuguese themselves, followed by the Spanish, and later through colonial invasions of the Dutch in the Northeast and the French in the Southeast region, especially in Rio de Janeiro State. Added to these flows of European, the slavery of black Africans, considered by some authors a forced migration through the institutionalized trafficking by the Kingdom of Portugal itself and later by the Empire of Brazil, led to the formation of a mixed Brazilian society -including the indigenous peoples -, multi-ethnic and multicultural (HOLANDA, 2012).

The first ethical dilemmas of immigration in Brazil - which will be discussed later - arise in this context of colonialism, and will be aggravated after independence in 1822 and with the Proclamation of the Republic in 1889, when immigration of Germans, Italians, Spanish and Japanese becomes a Federal Government program, designed to incorporate this workforce into the South-eastern coffee economy and settlement of the South, Midwest and North borders regions of the country.

From the World War 1 onwards and with the establishment of Getulio Vargas' Estado Novo(New State) dictatorship(SEYFERTH, 1999), immigration flows started being controlled by the state apparatus, i.e., the new immigrants such as Syrian-Lebanese, Swiss, Chinese and Koreans, among other nationalities, would become Brazil's new type of immigration: war refugees and builders of the final stage of Brazilian multicultural society.

After a period of almost half a century, due to the civil-military dictatorship implemented by the coup d'état in 1964, which ended in 1985, international migrations started the resumption of the flow to Brazil, initially with citizens from Mercosur countries in the 1990s, followed by the Bolivians in the 2000s, and the new flows from Haiti and West African Coast, especially Senegal and Ghana in the 2010s.

The economic boom experienced by Brazil from the neo-developmentalist government agenda since 2003 has opened space for new job positions not fil- 


\section{4}

led by Brazilians in the labour market and which, coupled with the country's strategic insertion in the Global South, has attracted immigrants from distant regions such as Bangladesh, India e Philippines and neighbours too, such as Cuba and Venezuela (in this case, most immigrants sought refuge and political asylum)and not just the traditional Brazil's immigration profiles.

That being said,Brazil's immigration profile today shows, according to the Federal Police data, the official migration authority, about 2,1 million immigrants in regular situation, besides others 500,000 undocumented migrants, according to the map in Figure 1, from Latin America and Caribbean, Western Europe, west coast of Africa and Southeast Asia.As mentioned in the introduction to this article, the immigration flow of the Syrians is also considerable, since they are the largest group of asylum seekers and refugees in the country who are from outside the continent.

Figure 1 - Map of the number of immigrants in Brazil by country of origin - 2011/2016

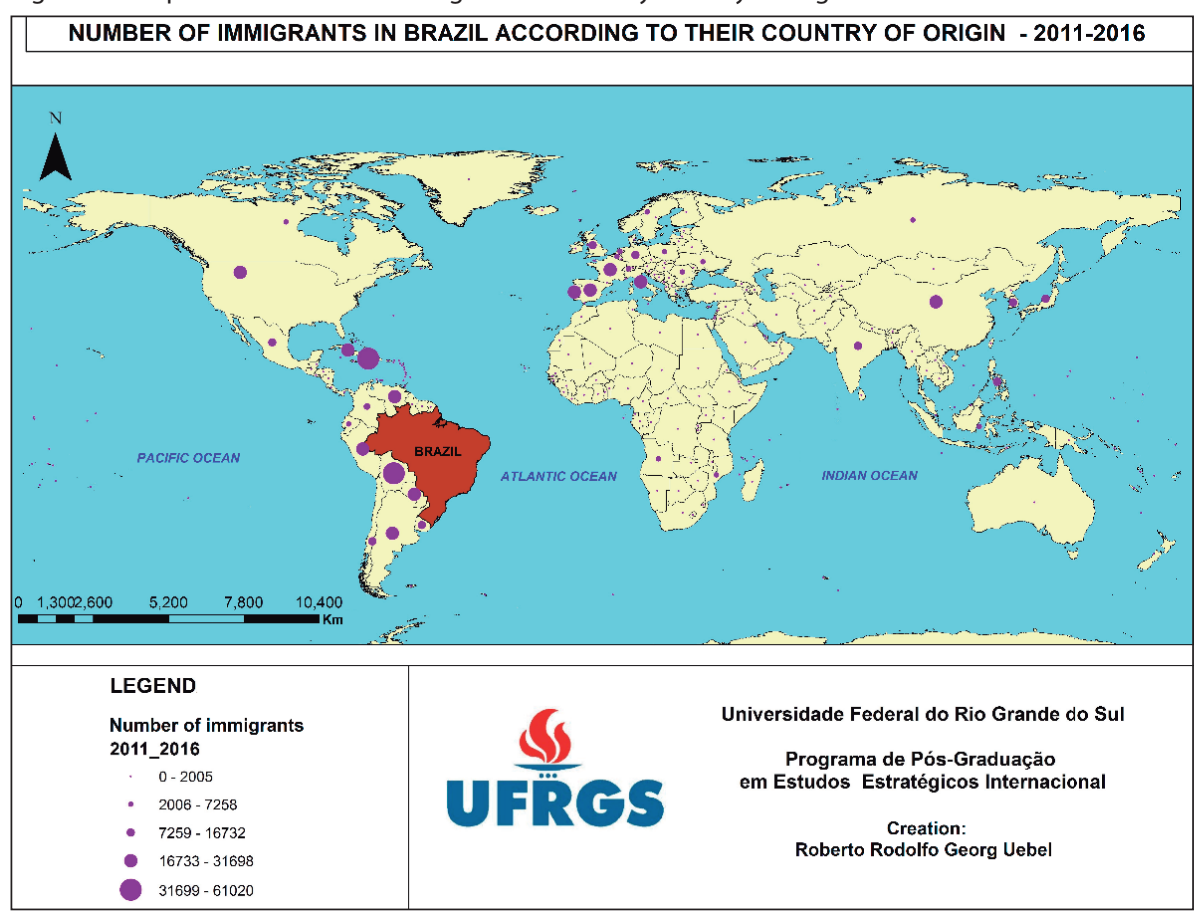

Source: Uebel (2018). 


\subsection{Brazilian Foreign Policy for Migrants and Refugees}

To understand how the international migrations to Brazil were motivated in the last two decades, it is necessary to discuss the role of the strategic insertion of the country in the migrants' countries of origin, that is, the reorientation of the Brazilian Foreign Policy towards the Latin America and Africa (HIRST; LIMA; PINHEIRO, 2010), namely, in this case, the countries of its west coast and the Luso-African states,called PALOP.

Starting from an "active and haughty" foreign policy agenda, a term coined by the then chancellor Amorim (AMORIM, 2017), the Brazilian government, from the Lula da Silva's administration until the beginning of the second Rousseff government, was based on some global themes which, according to their own interpretation, would elevate Brazil to a definite dreamt seat on the United Nations Security Council.

In this context, the Ministry of Foreign Affairs - Itamaraty - has prioritized topics that are important to the ethics to the very ethics of the contemporary international relations, such as humanitarian and peace missions, the fight against hunger and misery, gender equality, climate changes, eradication of child labour and analogous to slavery and, last but not least, international migrations.

Being the formulator of the Brazilian Foreign Policy for Migrants and Refugees, with full endorsement of the president of the Republic and with the minimal participation of some congressmen and civil society itself, Itamaraty drew the foundations of what Uebel (2018) identified as "Brazilian Foreign Policy for Migrants and Refugees", or that is, Brazil's foreign policy agenda for immigrants and refugees, which, to some extent, entitles the present paper.

Brazilian Foreign Policy for Migrants and Refugees(Política Externa Migratória Brasileira) - or PEXMB - differs from the national immigration policies from other countries such as Canada, Australia and Argentina, for example, as it is not an independent and exclusive national public policy for immigrants and refugees (MOREIRA, 2015), but rather a Brazilian foreign policy sub-agenda for these groups, with specific contributions from other federal agencies such as the Federal Police, the Brazilian Institute of Geography and Statistics, the National Immigration Council (CNIg) and the National Refugee Committee(CONARE), as well as sporadic participation of the Ministries of Economy, Justice and Health. 
Exposed that, it is possible to state that the entire Brazilian governmental agenda abroad was supported by an ethical axis, that is, a humanitarian bias, but with a practical objective already mentioned and that, after all, has sought to raise Brazil to a position of equal weight with the other major global powers, such as the United States, Russia, and China, not necessarily those that most respected the international ethics especially in the field of migration, our subject of discussion.

As part of PEXMB, which eventually influenced the Latin American and West African migrations to Brazil, it is possible to mention a number of strategic insertions and actions promoting the country abroad, such as: participation and leadership in humanitarian and peacekeeping missions in Haiti and in the African countries;granting scholarships and research fellowships through programs targeting Latin America and Africa, such as PEC-G and PEC-PG; technical, educational, cultural and sports cooperation agreements, that led to an increase of exchange of potential immigrants to Brazil; immigration subsidized by the Mais Médicos(More Doctors) Program; Brazil's positive imagery created by major world sporting events, such as the 2014 Football World Cup and the 2016 Olympics and Paralympics, with their respective visa waiver for tourists, where many immigrants entered Brazil using this way.

It is precisely from this strategic insertion and the specific programs mentioned before that was identified the first ethical issues involving migrants and the Brazilian State in our research: after all, these were projects developed by the Brazilian government to leverage its international projection, serving a purpose of launching the country as a global power, however, the repercussions brought a significant increase in immigration flows, absorbed at first by the job offer and, subsequently, rejected due to the worsening of political, economic and social crisis in Brazil from 2014 to 2019.

It is noteworthy, therefore, that the previously desired immigrant, became in a short period of time, what we call hyperdynamization of migrations, an unwanted social actor and bearer of all dissatisfactions of Brazilian society, which start realizing an increase in unemployment, social inequality and in civil-collective discouragement. Obviously, the new 2,1 million immigrants were not responsible for the Brazilian crisis, but they served as a speech for social dissatisfaction and a target of the Far-right political opposition, which was victorious in the 2018 elections. 
That being said, it is notable to observe that the contemporary immigration in Brazil, as a result of a federal and state policy, that is, the Brazilian Foreign Policy itself, has become an object of political and electoral discussion. This objectification resulted in episodes of effective xenophobia and persecution of immigrants, as depicted in Figure 2, with an unprecedented anti-immigration march, something that raise questions towards the ethical treatment of migrations by the Brazilian state and its government and that will be discussed in the next subsection.

Figure 2 - March against the new Immigration Law in SãoPaulo, on May16, 2017

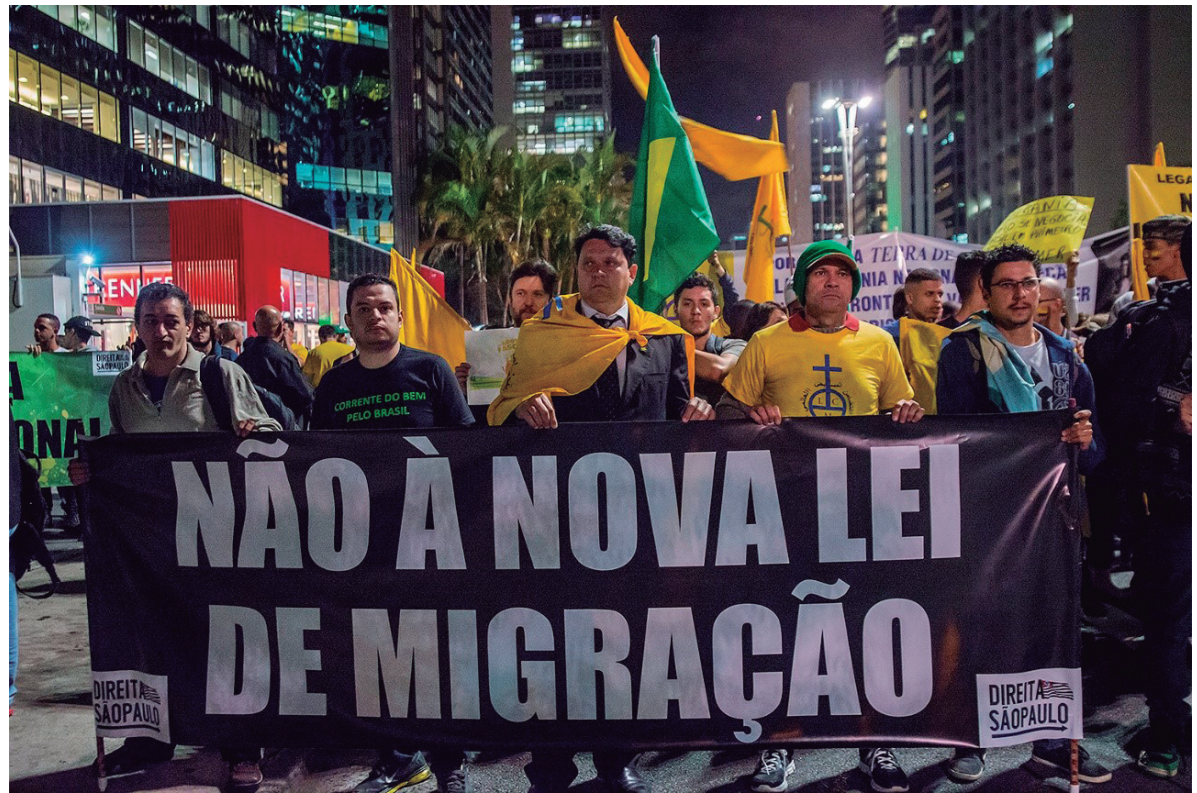

Source: Cris Faga/Fox Press Photo/Folhapress/Veja Magazine.

\subsection{Ethical Challenges and Contemporary International Relations}

In the field of International Relations, whether as a subarea of Political Science, or a process of interaction between the different international actors, the ethical dilemma has always been present, from the first schools of idealistic and realistic thought to contemporary, postmodern, critical and constructivist theories (SARFATI, 2005).

Regarding the international migration, the discussion arising from the decolonial and post-colonial and post-positivist theories has allowed the 
inclusion of the human mobility issue not only in the academic debates, but also in the work agenda of international organizations such as the United Nations itself and its specific agencies: United Nations High-Commissioner for Refugees (UNHCR) and the International Organization for Migration (IOM).

Having said that, the issue of the governmental and therefore state treatment of migration has reached a relevant ethical step in the International System and endorsed by international organizations, in other words, commitments have been established among states to ensure the dignity of migrants and refugees by its underwriters, although in practice reality is noticeable distinct from less developed countries, such as Bangladesh and the Rohingya People, to countries considered to have high Human Development Index, such as the United States and its severe anti-immigration policy against Latin Americans, which today is even materialized in border walls (THOMPSON, 2017).

In this regard, at least three international legal documents stand as guarantors of a minimal ethical and humanitarian treatment of migration, obliging signatory states to a series of protocols and standards, namely: The United Nations Convention on The Status of the Refugee - also known as the 1951 Geneva Convention -, the 1984 Cartagena Declaration on Refugees, and more recently, the 2018 Global Compact for Safe, Ordered and Regular Migration.

These three international legal landmarks allowed the migration issue to be treated by the states and governments through an ethical-normative prism until then inexistent, which entails, in the addition to the agreed obligations, a link between the domestic policies and a range of issues, such as social security,labour rights, access to public education and universal mental health, gender equality treatment,family reunification, human trafficking combat and unaccompanied child migration, etc.

The reflexes resulting from the incorporation of these themes considered ethical are also linked, according to Sassen (2007), to other contemporary International Relations topics, such as neo-colonialism, the securitization of borders, the statelessness issue and the diplomatic relations between nation-states. This way, the author draws attention to what it is described as "linking mechanisms" between different agendas of a national government in light of the key actor that is the international immigrant. 
Thus, it is possible to understand that the ethical challenges arising from international migrations are intertwined with the of the receiving state's own internal ethical demands, something that we will see later in the case of Brazil. After all, free and universal access to security, education, health, housing and welfare is a demand of both migrants and national citizens, so it is, as the name itself says, universal.

It is in the question of the universality of rights, guarantees and benefits where the main differentiators of the migration ethical questions are found, which are presented through xenophobia and its multiple aspects - social, institutional, governmental and media -, securitization of the borders, criminalization of migrations and the effervescence of nationalist, separatist and supremacist movements in both hemispheres. This is best represented when we analyse the main agendas of Far-right political parties in countries such as Germany, France, and the Netherlands, in the European case, and in the conservative party groups from countries formed by migrants, such as the United States, Canada, Brazil and Argentina.

To conclude this section, this paper resumes the work of Cardoso and Faletto(1979), who by mentioning the process of dependence and development in Latin America invoke the dual character of migration to Latin America countries: sometimes considering the immigrant as a labour force, useful, pioneering and formative of the nation-states, sometimes considering the migrant an undesirable individual, bearer of all the ills of the underdeveloped world and a threat of national and sovereignty security, the jobs of the national citizens and democracy itself, something that, we see as cyclical according to the economic momentum under analysis. In the case of Brazil, it will not be different.

The dependence relations diagnosed by the two authors (CARDOSO; FALETTO, 1979) imply in our analysis a crucial role in the development of international migrations internally in Latin America and, more specifically, in Brazil.The immigrant workforce in Brazil has in its dualities a dependence on the country's own performance in Latin America. The immigrant is not seen, at least nowadays, as a driving force for development, except in very exceptional scenarios, being characterized by other names, such as expatriates, for example.The interesting and shifting point, which we highlight here, is that these perceptions have come to be adopted even institutionally, reflecting, in one way or another, in Brazil's migration policy and in public policies that reach migrants and refugees. 
In the next subsection, therefore, it will be seen how the institutional agenda in Brazil is translated and a path to a practical application of the ethical treatment of migrations. It will be presented innovations brought by the new Immigration Law in force since2017, and the remaining legal and political issues of the extinct Foreigner Statute, redrawn in the anti-immigration speech of the Jair Bolsonaro's current government.

\subsection{Governmental Institutional Agenda: A Road to a Practical Application}

As observed in the previous section, the ethical treatment of international migrations is protected by interstate agreements, which allow for a minimum dignified and humanitarian treatment of human mobility, although in its practical application, object of this subsection, there is a distance, many times intentional and arbitrary, from the agreed cause.

In the case of Brazil, since 1980, therefore, still under the civil-military dictatorship, which began in 1964, the then Foreigners Statute was in force, which perceived the foreigners - there are only two mentions to the word immigrant in that legal text - as elements of potential threat to national security and sovereignty, especially in the labour field, and provided for a series of restrictions on immigration and refugee status itself, in full discussion at the time, due to the high flows of asylum seekers from the Union of Soviet Socialist Republics and its satellite republics ${ }^{1}$, such as East Germany, and from the exiles themselves from the Latin American dictatorial republics, including Brazil.

With the re-democratization of the country from 1985 on, which culminated with the promulgation of the new Federal Constitution in 1988 and the first direct elections in 1989, the Foreigners Statute lost practical applicability in favour of successive normative instructions from CNIg and CONARE, under the endorsement of the Ministry of Justice and supervision of the Federal Public Prosecution Service, and to a large extent was suspended by the new Refugee Law in 1997, considered one of the most modern refugee laws in the world.

1 Still at a time of great global tension due to the Cold War, migration flows from countries in the socialist bloc were perceived with caution by governments aligned with the United States, such as Brazil. In one of his chapters on West-East movements, Lowe (2005) discusses these issues. 
However, it was only after 37 years of validity that the Foreigners Statute was promulgated and replaced by the new Immigration Law, which began in Lula da Silva's administration, survived the political and parliamentary instability of the Rousseff governments and was finally promulgated in the government of Michel Temer, whose chancellor, Aloysio Nunes Ferreira, was one of the main authors of the bill that became Law n. ${ }^{\circ} 13.445 / 2017$.

In force since 2017, the new Immigration Law in Brazil has consolidated, although suffering some presidential vetoes directed by the military cabinet $^{2}$, a series of guarantees of rights to the new migrants, in addition to establishing the obligations of the Brazilian state, giving amnesty to immigrants in irregular situation and defining the guidelines of what was advocated as "Brazilian immigration policy", but in reality, it has not advanced beyond a governmental institutional agenda.

This government institutional agenda, which is called Brazilian Foreign Policy for Migrants and Refugees, presents as possibilities of practical application, a series of governmental programs based on the paternalist character of the Brazilian State, that is, top-down initiatives, however, with increasing participation of civil society actors, including immigrants and refugees themselves.

Among these possibilities of practical applications, it is necessary to draw attention to three examples, in which the ethical dimension can be perceived: a) the regional and national conferences on migration and refuge; b) the permanent human mobility forums; e c) immigrant collectives and associations, which until the promulgation of the new law in 2017, were considered illegal - to this day, foreign citizens, including immigrants, living legally in Brazil cannot vote or join political parties.

In the three cases mentioned above, Tedesco e Vanin (2018) find a similarity of institutional participation; the Brazilian state does not present itself directly through government agencies, but it is represented by state entities or public civil society organizations, such as trade unions, religious ministries, NGOs, business associations and professional councils. Non-executive state institutions, such as the Labour Public Prosecution Service, Attorney's

2 Invoking issues of security and national sovereignty, the military suggested vetoing some articles of the new Immigration Law. At the time, the Brazilian press reported this influence, as Araújo and Monteiro (2017) wrote. 
office and the Legislative committee commissions were the only representatives of the Public Power in these conferences.

Such scene points to a complex system of immigrant protection Brazil that is not led by the municipal, state and much less federal governments, but rather by state institutions, which became representatives, responsible and, often, intermediaries of migrants next to the Executive Branch, which advocates an ethical-legal question about the role of each state actor in the migration field.

The way forward for the practical application regarding this ethical challenge and arising from the possibilities of the new Migration Law stems, therefore, from the gaps of the Brazilian State in the attention of migrations. In short: the reason of xenophobic episodes against Senegalese, Haitians and Venezuelans to happen, it is because the state is not present in public security; IfBolivian and Syrian children are not enrolled in public schools, it is because the state is not present in education; If Cuban and Angolans fail to register with the Professional Councils, it is because the state is not obeying the constitutional principle of the efficiency of public affairs.

In this sense, the next section, which aimed at the practical application of the research problem, will point out how the Government Institutional Agenda can be accomplished and positivized in a context of new migration legislation and disconnection of the Executive Branch - or the State in general- to the demands of immigrants and refugees vis-à-vis the very economic, political and social scenario of contemporary Brazil.

\section{Practical Application}

The Brazilian Dictionary of the Portuguese Language (2019) presents two Luso-Brazilian definitions for the word ethics, namely: a) The branch of philosophy that aims to reflect on the essence of principles, values and fundamental problems of morals, such as the purpose and the meaning of human life, the nature of good and evil, the fundamentals of the obligation and duty, based on norms considered universally valid and that guide human behaviour; and b) Set of principles, values and moral standards and conduct of an individual, social group or society.

Therefore, it is possible to admit that a practical application of the ethical element in the research problem invokes a state conduct, in addition, the 
social and collective conduct is also necessary when migration issues in contemporary Brazil are considered. When an immigrant from a peripheral country seeks care at health or seeks regularization of their work documents and such services are denied by the Brazilian state, the ethical conditions described above arise.

What solution is presented through this practical application? The answer is obtained from two examples from recent Brazilian history. First, with regard to the Native peoples, protected by Federal Constitution of 1988, who have series of guarantees and rights in the most diverse fields of the State, especially in the professional field and integration with urban areas. The National Indigenous Foundation, a state-governmental agency in 1967 and linked to the Ministry of Justice and Public Security ${ }^{3}$, acts directly in the elaboration and conduction of the public policies for the Native Peoples.

The second, more recent example, is the policies of racial equality promoted since the government of Fernando Henrique Cardoso (1995-2002) which deal with a variety of themes that aim to include Afro-Brazilians in the Brazilian society, especially in the higher education, in the labour market and in the public service, and the culmination of which was the Special Secretariat for Policies to Promote Racial Equality, which had ministerial status in administrations of Lula da Silva and Dilma Rousseff .

These two examples summarize the argument that the approach to migration in Brazil should be done in the format top-down, since, as in the case of indigenous peoples and the Afro-Brazilians, a process of re-education of Brazilian society about the role and presence of immigrant communities in the country, including the historical rescue of Brazil's social formation, which is mostly mixed and multi-ethnic.

The collective awareness promoted through public agendas of Brazilian government and other government spheres -states and cities - also serves as one of the main pillars in 2018 Global Compact for Safe, Ordered and Regular Migration, which foresees not only integration and inclusion of immigrants and refugees in host societies, but also their social aggregation,

3 The National Indigenous Foundation has been part of several ministerial structures since the re-democratization, having its responsibilities initially divided, under the government of Jair Bolsonaro, between the Ministry of Justice and Public Security and the Ministry of Women, Family and Human Rights. In the past, it has always been linked to the Human Rights office. 
i.e., the cultural approximation, traditions, rights and guarantees between national citizens and the newly arrived foreigners .

It is possible to find scenarios in which social aggregation promoted by a national migration policy or agenda has led to successes, such as Canada, in the Northern Hemisphere, and Uruguay itself, Brazil's border neighbour, where an advanced approach is underway, among immigrants - many are from the same groups that migrated to Brazil in the last two decades - and the national society.

In the case of Brazil, the practical application of ethical treatment also involves reviewing the treatment of migration and governmental authorities, such as agents of the Federal Police and Labour Ministry(now Ministry of Economy), when dealing directly with immigrants and refugees, since there are reports of differentiated treatment of foreigners from central countries to the detriment of those from peripheral countries.

In addition, it is necessary to draw attention to one of the main ethical challenges, which could turn into a possibility of social aggregation in the future, which is the press's approach to immigrants and refugees, commonly portrayed through media sensationalism and in inappropriate language, as if they were illegal or clandestine individuals. In recent years, the Brazilian press has given much attention to the migration flows, however, with a background of poverty, violence and social vulnerability, instead of presenting positive possibilities for the reception of immigrants from countries with a cultural, ethnic and social plurality so diverse from Brazil, in order to build a multicultural country and open to globalization, as advocated in its own Foreign Policy.

In conclusion, it was identified in the extinct figure of National Conference on Migration and Refuge ( ${ }^{\text {st }}$ COMIGRAR), held in 2014, a retake possibility of the practical application of ethical treatment to immigrants and refugees, since it was an event that brought together more than two hundred governmental institutions, state-owned and non-governmental organizations, churches, academia, trade unions and immigrant associations, and outlined a National Immigration Strategy, represented by the National Books of Proposals, which advocated a hundred public policies, agendas and practical applications for the social aggregation of migrants in Brazil. 


\section{Conclusion}

This paper was an attempt to present a panorama of international migration in Brazil, as well as a concept of Brazilian Foreign Policy for Migrants and Refugees, i.e., the agenda for Migration from the foreign policy promoted by the Ministry of Foreign Affairs, one of the departments of the Executive Branch i.e., the Federal Government.

The socio-historical processes of migrations to Brazil also made it possible to identify a dual character assumed or portrayed by migrants already established in Brazilian territory, conditioned to their countries of origin and to the institutional view of the Brazilian government vis-à-vis those countries.

It was also promoted a discussion about the ethical challenges surrounding the country's Immigration issue, such as episodes of social, institutional and governmental xenophobia, and the difficulties created by the Brazilian state itself for the inclusion, integration and social aggregation of immigrants and refugees in the country, that is also a signatory of international agreements and pacts that advocate the ethical and humanitarian treatment of these groups.

Despite the current governmental agenda of not including migration ethics, the re-creation of the Ministry of Women, Family and Human Rights could try some possibility of practical application of state ethical treatment of immigrants and refugees, as seen in section 2 .

Thus, once again it is reiterated the importance of the top-down collective construction to: a) a re-education and e re-awareness of Brazilian society regarding the migration issue; b) The advancement of municipal and state public policies for immigrants and refugees; c) Adequacy of the Brazilian State to the international agreements mentioned at the beginning of the text, notably of those of Geneva, Cartagena e Marrakesh.

Just as the countries of the Northern Hemisphere faced the migration issue, either through crisis or through readjustment of national or regional legislation (as in the case of European Union), Brazil today faces the same issue, however, with a high burden of ethical dimensions and which is supported by the wishes of the civil society and the blocs of which is part such as MERCOSUR and the Organization of the American States.

As innovative points of this research, we highlight the role assumed both 
by the Brazilian government, and by its specific structure of the Ministry of Foreign Affairs, during the analysed period, as protagonists in the elaboration of immigration and refuge agendas. Until then, these issues always appeared fragmented in different governmental and political structures.

In summary, for the Brazilian State to address the international immigration topic in the country, with an ethical bias, in addition to putting into effect the new 2017 Immigration Law, it will be necessary a process of reconstruction of interrupted agendas in recent years and linked to reorientation of speeches and practices of government agencies, the press and the society itself. These are the main ethical, institutional and political challenges to be faced by Brazilian institutions, however, the positive examples border the country's history as presented in this paper, including the possibility of immediate application.

\section{References}

AMORIM, Celso. (2017), Acting Globally: Memoirs of Brazil's Assertive Foreign Policy.Lanham: Hamilton Books.

ARAÚJO, Carla; MONTEIRO, Tânia. Temer sanciona Lei da Migração com diversos vetos. 2017. Disponível em: https://brasil.estadao.com.br/noticias/ geral,temer-sanciona-lei-da-migracao-com-diversos-vetos, 70001812512. Acessoem: 22 abr. 2020.

CARDOSO, Fernando Henrique; FALETTO, Enzo. (1979), Dependency and Development in Latin America.Berkeley: UniversityofCalifornia Press.

HIRST, Monica; LIMA, Maria Regina Soares de; PINHEIRO, Leticia. (2010), "A política externa brasileira em tempos de novos horizontes e desafios". Nueva Sociedad, número especial, pp. 22-41.

HOLANDA, Sérgio Buarque de (2012), Roots ofBrazil.Notre Dame: University of Notre Dame Press.

LOWE, Norman (2005), Mastering Modern World History.London: Palgrave Macmillan.

MOREIRA, Julia Bertino. (2015), "Política Externa e Refugiados no Brasil: uma análise sobre o governo Lula (2003-2010)”. Carta Internacional, v. 10, n. 3, pp. 133-151.

SANTOS, Milton. (2017), Toward an Other Globalization: From the Single Thought to Universal Conscience.Cham: Springer.

SARFATI, Gilberto. (2005),Teorias de relações internacionais. São Paulo: Saraiva. 
SASSEN, Saskia. (2007), A Sociology of Globalization. Nova York: W. W. Norton \& Company.

SEYFERTH, Giralda. (1999),“Os imigrantes e a campanha de nacionalização do Estado Novo”. In: PANDOLFI, Dulce (Ed.). Repensando o Estado Novo. Rio de Janeiro: Fundação Getulio Vargas.

THOMPSON, Charles D., Jr. (2017),Border Odyssey: Travels along the U.S./ Mexico Divide. Austin: University of Texas Press.

UEBEL, Roberto Rodolfo Georg. (2017), “International Migrations to Brazil in the 21st Century: Profile, Outlook and Trends”. PopulationReview, v. 56, n. 1, pp.68-101.

UEBEL, Roberto Rodolfo Georg. (2018),Política Externa Migratória Brasileira: das Migrações de Perspectiva à Hiperdinamização das Migrações durante os Governos Lula da Silva e Dilma Rousseff. Tese de Doutorado. Universidade Federal do Rio Grande do Sul.

Submetido em 30 de dezembro de 2019

Aprovado em 04 de maio de 2020

\section{(c) (i)}

Licenciado sob uma Licença Creative Commons Attribution 3.0 